This is an accepted version of the below article published online on 4 November 2015 by Oxford University Press in International Studies Perspectives. Available at: http://dx.doi.org/10.1093/isp/ekv013

Accepted Version downloaded from SOAS Research Online: http://eprints.soas.ac.uk/21329/

\title{
1945's Forgotten Insight: Multilateralism as Realist Necessity
}

\author{
Dan Plesch and Thomas G. Weiss
}

\begin{abstract}
The 70 $0^{\text {th }}$ anniversary of the signing and entry into force of the UN Charter provided an occasion to explore the historical underpinnings of contemporary global governance. This essay redresses the neglect of the United Nations as a multilateral structure before the conference that drafted the Charter in 1945. It rehabilitates an underappreciated aspect of the period that began on 1 January 1942 with the "Declaration by United Nations," namely the combination of multilateral strategies for military and human security to achieve victory in war and peace. The wide substantive and geographic resonance suggests the extent to which the pressures of the second war to end all wars helped states to overcome their disinclination to collaborate. Today's fashionable calls for "good-enough" global governance abandon the strategy of constructing robust intergovernmental organizations; they are not good enough, especially because our forebears did much better. Many insights and operational approaches from 1942 to 1945 remain valid for addressing twenty-first century global challenges.
\end{abstract}

Keywords: United Nations; World War II; multilateralism; global governance; League of Nations.

The Liberal Jewish Synagogue London (1945) service at the end of World War II marked "The Victory in Arms of the United Nations," and comparable billings appeared in Christian services. Nowadays this description of "who won the war" seems odd enough to require fact-checking. Yet this United Nations defeated fascism with military might while it coordinated the building and planning of multilateral civilian organizations. This legacy of Allied efforts from 1942 to 1945 merits scrutiny as we grapple with collective problem-solving in the anarchical world of the twenty-first century. Can we do as well as the "greatest generation" without the "benefit" of another world war?

The rediscovery of the lost or the suppressed is a recurring theme in literature, mythology, and history from the Renaissance to Western popular fiction since World War II-Lord of the Rings and The Chronicles of Narnia and Star Wars. The UN at war provides another startling illustration of rediscovery. The wartime alliance of United Nations was formed in January 1942, some three-and-a-half years before the 26 June 1945 signing of the UN Charter in San Francisco. 
"We mean business in this war in a political and humanitarian sense just as surely as we mean business in a military sense"(Roosevelt 1943). Such was US President Franklin D. Roosevelt's message in November 1943, a few weeks before his first meeting with Soviet Premier Josef Stalin in Tehran. Roosevelt was addressing a White House conference that created the United Nations Relief and Rehabilitation Administration (UNRRA). Between 1943 and 1947, the Allied commitment to defeating fascism was displayed not only with military muscle but also this first operational humanitarian manifestation of that commitment; and also underway were planning efforts in other fields ranging from education to trade, from agriculture to aviation.

UNRRA's quintessentially liberal work was a Realist necessity not optional window-dressing. It remains the world's largest and most integrated, post-conflict aid and reconstruction body, which dispensed 1 percent of member states' gross domestic products in the years immediately following the war to support activities from China to Belarus, ranging from self-managed refugee camps to replacing industrial machinery. Nonetheless, UNRRA's pioneering multilateral efforts are all but invisible in scholarship, ${ }^{1}$ eclipsed by the bilateral Marshall Plan. Also languishing in obscurity are numerous other economic, political, and humanitarian creations of the United Nations during World War II.

Such efforts strengthened the political will of Allied populations and reinforced the diplomatic bonds among their leaders. The operational extension of the Allied multilateral commitment demonstrates the extent to which the lofty political rhetoric of war aims in the Declaration by United Nations and in the August 1941 Atlantic Charter were evident not only on the European and Asian fronts but also in a commitment to intergovernmental organizations (IGOs) and wide coordination of national policies among the 44 allied states. While "multilateralism" by definition involves cooperation by three or more states, our emphasis is on governance by the many as opposed to the few as was the case during World War II. While supposedly middle and smaller powers prefer multilateralism but major powers unilateralism, the wartime origins of the United Nations suggest a greater traction for wider multilateral cooperation by the most powerful as well when the political conditions are right.

That multilateralism matters should be obvious (Ruggie 1993). Yet this realization struggles to get an honest hearing. As we have argued elsewhere (Plesch and Weiss 2015a; 2015b; Plesch 2011), removing Cold War lenses eliminates a distortion and restores the experience in World War II, when multilateralism was critical to victory by energizing populations, combating the war appeasers, ensuring alliance cohesion, and stabilizing the immediate post-war world.

The proposition here is straightforward: There is a woeful neglect of the United Nations as a multilateral commitment and structure before 1945. Scholars and policy makers would do well to examine the sources of 1942-45 multilateralism, in particular how the pressures of a second war to end all wars created the conditions under which states overcame their disinclination to collaborate.

While anniversaries are sometimes gimmicks, nonetheless seven decades after the signing and entry into force of the UN Charter should give pause and call attention to the wartime United Nations and the historical underpinnings of contemporary global governance. Moreover, no longer are wars the only scourges to international order. The growing list of intractable problems ranges from climate change and migration to 
pandemics, from terrorism and financial instability to proliferation of weapons of mass destruction.

What remains unchanged after seven decades is that the policy authority and resources necessary for tackling such problems remain vested in individual states rather than collectively in intergovernmental organizations (IGOs). The fundamental disconnect between a growing number of global challenges and the current inadequate structures for international problem-solving and decision-making helps explain occasional, tactical, and short-term local views and responses instead of sustained, strategic, and longer-run global perspectives and actions.

The article begins with the rediscovery of the wartime United Nations because this pragmatic multilateralism contradicts the conventional wisdom that liberalism was abandoned to confront the Nazis and Imperial Japan; Multilateralism in the 1940s was conducted under the banner of Thomas Hobbes rather than Immanuel Kant. The next section documents the diverse inputs into the period, which makes even more intriguing the historiographical question about why the wartime UN has disappeared from academic and policy consciousness. The article continues by drilling deeper into the history of international cooperation during the war, which obliges us to move beyond fashionable calls for "good-enough" global governance. Elucidating the global sprawl of networks and informal institutions does not solve the basic dilemma that we need strengthened intergovernmental organizations (IGOs), most especially the United Nations, not more coherent pluralism,

\section{Pragmatic Multilateralism}

"Whether our accumulated connectivity and experience has created fresh perspectives on global governance and an ability to transcend national orders," Ian Goldin writes, "remains the most critical question of our time" (2013: 166-167). The practical vision of the 1940s should shock us from the twin complacencies that we are doing the best we can, and that our best today is better than yesterday. The ancient Greeks would appreciate the tragedy if we allow ourselves to drift into catastrophe in the twenty-first century, having discarded or forgotten lessons learned at such cost in the last.

Past efforts, successful or less so, provide important stepping stones toward the future. Peering through the lenses of global governance offers a way of not writing off or ignoring substantial, albeit inadequate, previous efforts to fill major gaps in governing the globe: in knowledge, norms, policies, institutions, and compliance (Weiss and Thakur 2010). Among such lessons are those that go beyond the military efforts by the "greatest generation" and that largely ignore the "softer" side of wartime efforts by the United Nations. Military historian Michael Howard and former UN official Edward Mortimer, for instance, agree that reassessments of the conduct of the war and the origins of the Cold War challenge assumptions that underpin military-centric policy-making to this day (Plesch 2011: endorsements).

US Lend-Lease military supplies to allies began in March 1941 and were critical to a prompt victory; but they were under attack from Congressional Republicans throughout the war, on grounds ranging from unalloyed isolationism, reluctance to support a Communist army against the Nazis, and objections to bolstering British and other imperialism. John Lewis Gaddis (1986) observed with approval that shortly after the war a 
consensus emerged in Washington that forcing unconditional surrender on the Third Reich had been a mistake. This view shocks when we realize that even during the war, Roosevelt had to counter pro-Nazi advocates. With Republicans in the lead, Congress almost demobilized the US Army in August 1941 (Bendetsen 1972). Then, weeks after the German surrender at Stalingrad, the Republican leadership in Congress tried to cut-off US supplies that had provided 10 percent of the planes and tanks in the battle and much of the food and trucks (Van Tuyll 1989; Lebedev 1997). Roosevelt's counter was to reach out to Republicans - Henry Stimson, his secretary of war, was a Republican until rejected by his party for aiding the war effort. In countless statements and initiatives, the president made his Four Freedoms and then the United Nations "in war and peace" the core of his strategy. He told Congress that Lend Lease was a United Nations enterprise essential to victory and post-war security. ${ }^{2}$

Reference is often made to the collapse of idealism at the end of the war with the double shock of Hiroshima and the growing tensions between the West and the Soviet Union. Little if any attention, however, is paid to the potent mixture of realism and idealism that was relevant for Lend-Lease but apparently is irrelevant today in Washington, where "we don't do social work." However, that was precisely an essential US contribution in World War II alongside its military muscle. "It is not impossible that postwar organization will be the product not of one embracing covenant or constitution," one commentator wrote already in July 1942, but "learning to work together on everything from ships and tanks to tea and quinine" (Wild 1942: 94).

Indeed, a host of Allied efforts - including international criminal justice, post-war reconstruction, international development, regulated world economic activity, public diplomacy, and agricultural and educational policy - provided the foundations for postwar stability in addition to sustaining the wartime military enterprise. No one sought a return to the chaotic pre-1914 world despite the abject failure of the League of Nations. Unilateral military might was not regarded as a viable option.

The establishment of the UN system was not peripheral but rather central to policyand decision-making - not least as a means to reduce direct requirements on Washington after the war. At a moment when one might have expected the disaster of the failed Kantian experiment of the League to have produced a Hobbesian reaction on steroids, those at the helm were resolute that multilateralism and the rule of law, not going-it-alone and the law of the jungle, were the foundation for the post-war order. In fact, the bleak contrast was the Third Reich, the epitome of the right of might and lawlessness.

The combined national decisions to work together and to construct the subsequent organizations for peace and prosperity central to the original mobilization against fascism reflect an enlightened Realism about the merits of multilateralism. It was not the "false promise of international institutions" (Mearsheimer 1994/5: 5) but rather a genuine cooperative strategy that motivated peoples and kept states allied. Multilateralism was tangible and the post-war vision more than propaganda, ${ }^{3}$ although "business-as-usual" quickly returned as the default option with the Cold War's onset.

Governments pursued traditional vital interests, to be sure, but the wartime United Nations was far more than a temporary multilateral charade to be tossed aside as soon as the armed conflict ended. The "United Nations" was not merely a brand to sell the AngloAmerican alliance. We do not imply that the UK-US military effort included other states 
in the planning or that the voices of the weaker and smaller members of the coalition were as loud as those of the major powers (Woolner, Kimball, and Reynolds 2008). However, it was not the weakness of international cooperation but the intensity of the Cold War that replaced a multilateral commitment with a narrower vison of cooperation.

Despite the failed League of Nations, neither governments nor analysts considered a return to the world of 1913. If that had been the case, Allied governments might have insisted on Spartan educational methods to prepare their populations for the next war; or reciprocal mass atrocities perpetrated against the Germans; or bombing Moscow as an encore to Nagasaki. Something fundamental had changed.

That such retribution did not occur should be puzzling; to win and yet not seek revenge and plant the seeds for the next war was not an approach much in evidence in Western history, save in limited form after 1815. The post-World War II peace was not supposed to reflect a Metternich-like management of nationalisms but cooperation among friends and rivals. While falling short of the Biblical call to "beat their swords into plowshares," there was movement toward another aim of Isaiah (2:4), "neither shall they learn war anymore." Why did the Conference of Allied Ministers of Education during 1942-45 seek insights about healing the wounds of war rather than rubbing salt in them? Or why, for that matter, did governments from Washington to Panama help UNRRA rebuild the dikes along China's rivers with Canadian timber, send cattle to replenish the farms of Ukraine and locomotives to Yugoslavia? Or why bother with the official UN conference at San Francisco at which the Brazilian feminist Berta Lutz could get women's equality woven into the Charter's fabric? (Skard 2008)

Governments largely set aside a self-destructive mind-set even while their militaries were keeping their powder dry for an East-West confrontation. The 1914-18 carnage was so dreadful for so many societies that widespread revulsion arose against its repetition. This disgust proved insufficient and the next war resulted from even more extreme racist militarism, which made vulnerable governments and their citizens more rather than less determined to do better the next time around. In 1948 the commissioners of the UN War Crimes Commission (UNWCC) underlined this rationale in a final report of activities since 1943:

One side, that of the Axis, asserted the absolute responsibility of belligerents, who, it was asserted, were under no obligation to respect human rights, but were entitled to trample them underfoot ... This doctrine was repudiated as contrary not only to morality but to recognized international law which prescribed metes and bounds for the violation even in war of human rights (UNWCC 1948).

Learning from 1942-45 should recall efforts to salvage viable components from the general wreckage of the League of Nations (Webster 2005; Pedersen 2007; Clavin 2013). The wartime thinking of the 1940s included earlier international efforts to pursue economic and social development, care for refugees, pursue minority and human rights, and recruit independent international secretariats. The League's toxic brand was disavowed, but its staff and working methods were in demand as planners sought to reassemble building blocks for the next generation of intergovernmental organizations (Ranshofen-Wertheimer 1945). 
At the final session of the League's Assembly in 1946, one of its founders and ardent defenders, Lord Robert Cecil, uttered his memorable sound bite: "The League of Nations is dead; long live the United Nations." It is striking how many of the supposedly discredited ideas associated with the defunct League reappeared (Cottrell 2014). Leland Goodrich, a member of the US delegation, explained: "Quite clearly there was a hesitancy in many quarters to call attention to the continuity of the old League and the new United Nations for fear of arousing latent hostilities or creating doubts which might seriously jeopardize the birth and early success of the new organization" (1947: 3).

The British and other Europeans were motivated to follow almost any US lead that would - in contrast to the collapsed League without Washington-bind the United States to a post-war order and help pacify Germany and Japan as well as the Soviet Union. For much of the time since 1945, however, national policy makers - and certainly those in Washington - have seen little need to invest political capital in the world body although more has been devoted to regional organizations. A fresh look at the effectiveness of and investment in liberal internationalism to win World War II could elevate the earlier strategy as a benchmark in comparison with today's routine derision of intergovernmental organizations.

Since Harry S. Truman's visceral anti-communism replaced Franklin D. Roosevelt's multilateralism, the United States has not replicated its World War II success. In sporting terms, the "wins" in the 1991 Gulf War and in the Balkans can be set against the "tie" in Korea and the major losses in Vietnam, Iraq, and Afghanistan. Umpires are still debating who or what led to the collapse of Communism and whether the Cold War and its fourdecade duration were necessary. In retrospect, the impact of Roosevelt's progressive era strategy looks remarkable. "The mix of realist power politics and idealist aspirations," write two commentators," that marked the negotiations at Dumbarton Oaks, Yalta, and San Francisco has been a defining feature of the Charter and the UN ever since" (Shapiro and Lampert 2014: xv).

\section{Multilateralism's Wide Geographic Purchase}

The simple morality tale of military triumph, usually told as an Anglo-American story that arguably is the defining experience of contemporary world politics, is really only part of the story. State leaders and publics alike who contemplate the problems of the twenty-first century should revisit the striking 1942-45 investments of political, human, and financial capital in projects that recognized the overlap between international and national interests. Wartime efforts demonstrated the value of broad-gauged multilateral collaboration, although the number of states was only a quarter of the number in contemporary IGOs.

We illustrate the twenty-first century relevance of the wartime United Nations with UNRRA and the UN War Crimes Commission. We could have pointed to the Keynesian economic strategy designed to prevent the recurrence of the Great Depression brought to fruition at the United Nations Monetary and Financial Conference-better known by its location, Bretton Woods - including the concerns not only with finance, development, and trade but also such "softer" issues championed by functionalist as education and agriculture. Space limitations dictate a focus on helping forcibly displaced people and prosecuting war crimes, two topics still prominent on the international agenda. 
With a booming humanitarian business and veritable cottage industry of postconflict peace-building challenges (Weiss 2013b), the current UN system and its member states could learn from UNRRA's policies and practices. Among other things, the fraught contemporary notions of "One UN" and "Delivering as One" could usefully adopt UNRRA's central procedures, which aimed to create self-managed and democratically-run refugee camps, set up divisions for industrial and agricultural reconstruction, and provide emergency relief of food, welfare, and health (Weiss 2012). Because other "temporary" intergovernmental and nongovernmental organizations continued while UNRRA did not, the value of sunset clauses for other intergovernmental bodies is a topic for further reflection. The 2010 creation of UN Women, for example, by merging four smaller UN bodies was almost unprecedented in UN history.

Another fruitful historical illustration is international criminal justice. According to the former chief prosecutor of the International Criminal Tribunal for the former Yugoslavia, Richard Goldstone (2014), international judicial bodies pursuing such key issues as sexual violence and collective criminal responsibility could have done so more resolutely had archival research into the work of the UNWCC been available at the outset of the 1990s (Plesch and Sattler 2013). Indeed, this substantial body of overlooked customary international criminal law could substantially reinforce today's efforts. ${ }^{4}$

In 1943, states established the 17-country United Nations War Crimes Commission to support national trials of thousands of "minor" war criminals alongside those of 24 individuals on the dock in Nuremberg and the 28 in Tokyo. It was common for national tribunals to prosecute widely for torture with endorsement from the UNWCC. The original concept was to pursue as many perpetrators as possible - a practical recognition that accountability and effective deterrence required more than symbolic prosecution. Today, there often is not even that - prosecutions follow the Nuremberg and Tokyo models to pursue the top leadership but not the foot-soldiers of mass atrocities.

Moreover, the worldwide resonance of such efforts, among states and non-states alike, holds additional lessons. A growing number of historians share a conviction that the UN's wartime origins, like the history of any epoch, cannot be understood merely in terms of separate national or even regional histories but must encompass the global context (Iriye 2014). As a result, the depiction of the victory over the Axis powers as an AngloAmerican undertaking - with the addition of the Soviet Union's contributions on the Eastern front and an occasional mention of China-must be modified.

As deliberations occurred before rapid subsequent decolonization- 50 states participated in San Francisco whereas today's UN membership numbers 193-it is tempting to simplify the narrative as the West without the Rest. However, the details of Imperial India's and China's contributions to early efforts to pursue war criminals and determine the post-war direction of assistance to refugees and displaced persons and of trade and finance, for instance, complicate the story-line. More powerful countries, and especially the United States, had more say during such deliberations; but that reality is always and hardly destroys the argument that multilateralism mattered. Other voices from countries in what is now called the "global South" were on stage and not merely in the wings, including 19 independent states from Latin America and others whose independence was more recent: 3 from Africa (Ethiopia, Liberia, and South Africa); 3 from Asia (China, the Philippines, and Imperial India); and 7 from the Middle East (Egypt, Iran, Iraq, Lebanon, Saudi Arabia, Syria, and Turkey). By the 1970s decolonization had 
proceeded apace, and two-thirds of UN member states were in the limelight as erstwhile colonies; but the stage was set in 1942-45.

Throughout the war and the drafting and adoption of the UN Charter in San Francisco, less powerful states influenced the agenda and advanced their own interests and ideals. The Latin American emphasis on regional arrangements in Charter Chapter VIII was one such result; and Chapters XI and XII regarding non-self-governing territories and trusteeship reflected the widespread views of recently decolonized states and other advocates of self-determination (Rhagavan 2014).

The wartime and immediate post-war United Nations was not simply dictated by the West even a generation before decolonization. Other research shows the extent to which Southern agency has long been an underappreciated source of global norms (Helleiner et al. 2014). Indeed, rapid decolonization is hard to imagine in the form and with the speed that it took place without World War II's multilateralism.

Twenty-first century discourse in China, India, and other emerging powers as well as in poorer developing countries accepts the Anglo-American mythology, perhaps as a facile justification for distancing themselves from the "old order" and its 1945 institutions (Weiss and Abdenur 2014). A clearer appreciation of liberation in the context of wartime deliberations might provide the basis for a new "internationalist"- perhaps even a "postnational" one in which the definition of narrowly defined vital interests would expand to include consideration of a perspective that ignored borders - approach to global affairs more suited to problem-solving than the them-versus-us template that characterizes what customarily passes for international negotiations.

Various non-state actors helped shape post-war institutions-independent commissions studying the lessons of the past for future application, nongovernmental organizations (NGOs) delivering aid or lobbying, and other civil society actors, including the media and business, were involved in the fray. We are hardly the first to remark that the world is more interconnected than it used to be, and that actors besides states are consequential. However, the wartime experience already suggested the ease of establishing all manner of entities and coalitions, of multiplying interactions and impact. This reality was a manifestation of the variable geometry of "transnational relations" or "global governance"- - before this term emerged in the 1990s despite earlier manifestations and pertinence (Murphy 1994; Weiss and Wilkinson 2014a). Over the past century, there has been a marked increase in the number and scope of actors on the world stage, and their burgeoning numbers have been concentrated in non-state actors, specifically in international NGOs and transnational corporations (TNCs). Their numbers were more modest, but their voices were nonetheless audible in the wartime and immediate post-war United Nations.

In short, World War II provides additional evidence of the extent to which states and non-state actors have cobbled together frameworks for cooperation and responses that have produced more order, stability, and predictability than might be expected. They have contributed to improving global governance, which goes beyond a formal system of coordination by state-based entities and embraces an evolving system of partnerships. While states remain the dominant variables in world politics, they are no longer alone, a reality evident during World War II. 
In short, even during World War II, the state-centric model of traditional international relations failed to capture accurately international dynamics. In addition, more than Western values and notions were on the drawing boards of the wartime United Nations and ultimately in the Charter.

\section{Historical Grounding and Global Governance}

An ironic obstacle to better understanding World War II's significance for contemporary analysis is that mainstream international relations has shifted so dramatically away from the study of international organization and law toward global governance (Weiss 2013a; Weiss and Wilkinson 2014b). The term was born in the 1990s from a marriage between theory and practice and became entwined with another meta-phenomenon, globalization. The theoretical volume Governance without Government (Rosenau and Czempiel) was published in 1992, just about the same time that the Swedish government launched the policy-oriented Commission on Global Governance under the chairmanship of Sonny Ramphal and Ingmar Carlsson. The publication of the commission's report, Our Global Neighbourhood (1995), coincided with the first issue of the journal Global Governance. This quarterly sought to return to the immediate postwar origins in 1946 of the leading journal in the field, which seemed to have lost its way. "From the late 1960s, the idea of international organization fell into disuse," Timothy Sinclair reminds us. "International Organization, the journal which carried this name founded in the 1940s, increasingly drew back from matters of international policy and instead became a vehicle for the development of rigorous academic theorizing" (2012: 16).

Global governance explores collective efforts to identify, understand, and address worldwide challenges and processes that go beyond the problem-solving capabilities of individual states. It encompasses cooperative problem-solving arrangements that are visible but informal (e.g., practices or guidelines) or are temporary formations (e.g., coalitions of the willing). Such arrangements can also be more formal, taking the shape of hard rules (laws and treaties) or else institutions with administrative structures and established practices to manage collective affairs by a variety of actors-including state authorities, intergovernmental organizations, nongovernmental organizations, private sector entities, and other civil society actors. Perhaps most importantly for our purposes here, the United Nations is a modest player in filling gaps in global governance; but that role is far more peripheral than that played by the wartime United Nations or imagined for the postwar world organization.

It is commonplace to declare borders irrelevant for many intractable global problems. Again, an examination of 1942-45 demonstrates that more ambitious and cosmopolitan visions can sometimes overcome the navel-gazing of governments and their constituents. The current generation of IGOs undoubtedly lessens transaction costs and overcomes structural obstacles to cooperation as should be clear to anyone examining responses to the 2004 tsunami or on-going humanitarian crises in Libya or Syria for which we see a constellation of helping hands - soldiers from a variety of countries, UN organizations, large and small NGOs, and even Wal-Mart.

While global governance is not the continuation of traditional power politics, it also is not the expression of an evolutionary process based on multilateral commitments that could result in intergovernmental structures capable of addressing contemporary or future global threats. Moreover, to speak of "governance" and not "government" is to discuss the 
product and not the producer. In the national context, governance adds to government. For the globe, governance is essentially the whole story, amounting to Scott Barrett's "organized volunteerism" (2007: 19) with the United Nations at its pinnacle.

E. H. Carr viewed history as an "unending dialogue between the past and the present," (1961: 62) and so the plea to learn lessons from the past for today and especially tomorrow should resonate. In contrast with Marxists who have long emphasized the march of history, the ahistorical quality of too much contemporary social science and international relations is remarkable. ${ }^{5}$ One explanation is parsimony and the premium for the simplest theories and causal mechanisms. As such, history can complicate matters but also make fundamentals clearer (Williams, Hadfield, and Rofe 2012).

There is a powerful overriding consideration to which our longer-term perspective leads. Realists point to the obvious absence of an overarching central authority; and they conclude that only self-help is sensible. Liberal institutions are a failed dream-and a "pipe dream" at that. The realities of the wartime United Nations and its legacy institutions lead us to a different conclusion: the fear of conquest and annihilation can drive states toward genuine multilateralism. The virtually exclusive focus on military victory in World War II has meant that the more comprehensive multilateral tactics and strategy of 1942-45 remain under-explored.

\section{Is good-enough global governance good enough?}

Andrew Hurrell (2002: xiii) reminds us about the "relentless presentism" that afflicts political science and international relations, a sort of inverse Alzheimer's disease: shortterm memory is retained while the contexts that crafted these memories have slipped away. We are not starting from scratch. Despite gridlock, some current global problems reflect past successes with international cooperation-for instance, more states as a result of decolonization; more globalization as a result of trade liberalization; more institutions as a result of collaboration and specialization; and more environmental degradation as a result of growth (Hale, Held, and Young 2013).

The rediscovery of the wartime United Nations defies received wisdom about UN efforts during World War II. For those who examine primary sources, the UN was in the pages of the Foreign Relations of the United States, mainstream international relations journals, and newspapers as well as on the agendas of town-hall meetings and university faculties.

This proposition flies in the face of an infatuation with problem-solving by anything other than IGOs. A decade ago, Anne-Marie Slaughter (2004) viewed networks of various types rather than actual organizations as the key problem-solving formula. More recently, Dan Drezner (2013) and Stewart Patrick (2014) have proposed living with the sum of alternative arrangements and dismissed the universal-membership United Nations as hopeless and hapless. Apparently, we can only aspire to a variegated institutional sprawlor "good-enough global governance" (Drezner 2013).

Alas, that is not and will not be adequate without a revitalized United Nations as an integral component of international society. Scepticism about UN capacity are justified, but we are kidding ourselves about the potential of mini-lateralisms - what the Human 
Development Report 2013 hopes somehow will constitute "coherent pluralism" (UNDP 2013: 112).

Those struggling in the midst of the last truly world war thought otherwise. The Declaration by United Nations committed the Allies to multilateralism not only to fight fascism in the short term but also over the longer term to maintain international peace and security and to foster post-war economic and social stability.

When governments decide to make use of intergovernmental organizations, they work. UNRRA, we should recall, was an important humanitarian and strategic weapon until the Cold War made it imperative to pursue the more restricted Marshall Plan. To fast forward, the value of a functioning Security Council was demonstrated in authorizing action to halt Colonel Muammar al-Gaddafi's murderous designs on Benghazi. The reverse could be said about Syria where the absence of political will among the permanent five members has facilitated that human abattoir. But even there, when the politics were right and the need arose for a face-saving way to dispose of Bashir al-Assad's chemical weapons, the universal UN was called upon for an authorization and for work with the Organization for the Prohibition of Chemical Weapons.

The wartime convictions of the UN's founding fathers (only a few mothers) suggest that global governance is a second-best surrogate for more robust multilateralism. Whatever scepticism is prompted by the intergovernmental landscape should be dwarfed by a dominant reality: if global problems require global solutions, we also require strengthened IGOs, especially those of the UN system.

While Hedley Bull (1977) and the English School usefully remind us that there is more stability and predictability in world politics than an anarchical international system might lead us to believe, universal-membership intergovernmental organizations are anemic and atomized. Hence, we need to do more than throw up our hands and hope for the best from hordes of norm entrepreneurs, activists crossing borders, epistemic communities, profit-seeking corporations, and transnational social networks. Non-state actors can make and have made essential contributions to global problem-solving. Not to put too fine a point on it, however, they can do little to safely manage geopolitical competition or control the spread of advanced weapons - let alone eliminate poverty, thwart pandemics, fix climate change, ensure macroeconomic stability, agree on international standards, or halt mass atrocities.

The downside of good-enough global governance, which contrasts starkly with the approach and operations of the wartime United Nations, is misplaced enthusiasm for what amounts to a "Global Tea Party" - downplaying the consequences of and possibilities for ad hoc and inadequate pluralism rather than exploring the necessity for systematic and multilateral responses. There are many potential and valuable partners in today's variable architecture of global governance; but their limitations should be obvious as well. Without more robust IGOs, especially universal ones like those launched during and after World War II, states and their citizens will not reap the benefits of trade and globalization, discover nonviolent ways to meet security challenges, or address environmental degradation.

The under-staffed and under-resourced organizations that constitute the contemporary UN system have limped along rather than assumed the dimensions foreseen 
by planners during World War II. A three-pronged strategy is necessary in the decades ahead: the continued evolution and expansion of the formidable amount of practical global governance that already exists; the harnessing of political and economic possibilities opened by the communications revolution that began late in the last century; and the recommitment by states to a fundamental re-vamping and strengthening of the United Nations.

Identifying the conditions under which multilateralism's appeal in 1942-45 overcame the recalcitrance of states to collaborate results in two queries: Must the next generation of multilateral organizations arise as a result of unnecessary and unspeakable tragedies - as the United Nations did from the ashes of World War II? Or could more robust institutions result from learning lessons about how best to address felt needs that clearly do not respect borders?

The first question is un-nerving because cataclysms are the customary currency for global institutional reforms (Gilpin 1981). Nonetheless, a human capacity exists for learning and adapting; and it is unnecessary to await suffering on a scale that could well dwarf that of World War II. Deoxyribonucleic acid (DNA) was originally thought to be immutable but is now found to be adaptable within a living creature. We should thus not act as if today's international political order were immutable or pre-ordained.

The 1940s should give us the courage to formulate ambitious visions about improving future world orders. The need for intergovernmental organizations with teeth is too often short-changed in thinking about global problem-solving. Perhaps they have always been too few in number and arrived too late on the scene and with too little state backing. But in the second half of the second decade of the twenty-first century, addressing collective-action problems requires refurbishing or creating more muscular intergovernmental organizations with wider scope, more resources, and additional democratic authority (Shwartzberg 2013; Plesch 2004). Merely identifying the global array of networks and institutions will be inadequate to address life-threatening, transboundary problems.

\section{Conclusion}

Returning to the wartime origins of the United Nations helps to move the conversation beyond cherished notions. Like Samuel Johnson's reflection on hanging, World War II created conditions under which governments were wise enough to overcome their traditional reluctance to cooperate and focus on multilateralism as a strategy and a tactic. Liberal institutionalism helped ensure the classic Realist objectives of state survival. The 1942-45 United Nations was not merely an inter-state security forum but also a short-lived apex of global governance.

The lesson for great and emerging powers as well as for analysts is clear: there is no need to sneak multilateralism on the agenda; it should be in bold-faced print. Before eyes glaze over at the suggestion, we should recall that even during World War II, some observers also did not see the need for urgent action; or, worse, some even sought to preserve their narrow interests at the expense of the rule of law and the larger international community of states. Then as now, success was hardly guaranteed-indeed, the Allied victory was a close call, and in some ways it is remarkable during the war that discussions took place at all about the shape of international organization. 
A few weeks before D-Day with the outcome still in the balance, Roosevelt sent an address to delegates gathered in Philadelphia to reaffirm the objectives of the International Labour Organisation (ILO), founded in 1919 after World War I. His reflections about building IGOs as a realist necessity have an eerie resonance: "We know that the conditions of a lasting peace can be secured only through soundly-organized economic institutions, fortified by humane labor standards, regular employment and adequate income for all the people" (1944).

While armchair speculation is usually unproductive, it is hard not to pose a counterfactual about the shape of contemporary global problem-solving had wartime collaboration endured beyond World War II's killing fields. The insights and visions for the post-war order so prevalent from 1942 to 1945 remain valid for twenty-first century challenges ranging from terrorism to pandemics, from proliferation to financial instability. Can history repeat itself? Do we have the wit and will to do what is necessary without a global conflagration?

\title{
Notes
}

\begin{abstract}
** Dan Plesch is Director of the Centre for International Studies and Diplomacy at SOAS, University of London. His most recent authored book is America, Hitler and the UN (2011). He previously worked for the BBC and CNN, the Royal United Services Institute and was the founding director of the British American Security Information Council (1986-2000). His other books are The Beauty Queen's Guide to World Peace (2004) and A Case to Answer (2004).
\end{abstract}

Thomas G. Weiss is Presidential Professor of Political Science at The Graduate Center of The City University of New York and Director Emeritus of the Ralph Bunche Institute for International Studies, and Research Professor at SOAS, University of London. Among his recent authored books relevant for this essay are: Governing the World? Addressing "Problems with Passports" (2014); The United Nations and Changing World Politics (2014); Global Governance: Why? What? Whither? (2013); and What's Wrong with the United Nations and How to Fix It (2012).

The authors of this article have drawn upon their edited volume Wartime Origins and the Future United Nations (London: Routledge, 2015) and essay “1945's Lesson: 'Good Enough' Global Governance Ain’t Good Enough,” Global Governance 21, no. 2 (2015): 197-204. They express their appreciation to contributors of the edited volume (Manu Bhagavan, Stephen Browne, John Burley, Miriam Intrator, Ruth Jachertz, Eli Karetny, J. Simon Rofe, Pallavi Roy, and Giles Scott-Smith) as well as to Shanti Sattler, Sutha Nadarajah, and four anonymous reviewers.

\footnotetext{
${ }^{1}$ An exception is Reinisch (2008, 2011, 2013).

${ }^{2}$ Kimball's classic (1969) ignores these dynamics.

${ }^{3}$ For other views, see John Cull (1995) and Brewer (2009).

${ }^{4}$ Digital archives available at www.unwcc.org.

${ }^{5}$ Exceptions include Buzan and Lawson (2013).
}

\section{References}


BARRETT, SCOTT. (2007) Why Cooperate? The Incentive to Supply Global Public Goods. Oxford: Oxford University Press.

BENDETSEN, KARL R. (1972) Oral History Interviews with Karl R. Bendetsen. Harry S. Truman Library and Museum. Available at: http://www.trumanlibrary.org/oralhist/bendet.htm (Accessed March 20, 2014).

Brewer, Susan A. (2009) Why America Fights: Patriotism and War Propaganda from the Philippines to Iraq. Oxford: Oxford University Press.

BuZAN, BARRY, AND GEORGE LAwsON. (2013) The Global Transformation: The Nineteenth Century and the Making of Modern International Relations. International Studies Quarterly 57 (3): 620-634.

Bull, Hedley. (1977) The Anarchical Society. New York: Columbia University Press.

CARr, Edward HalletT. (1961) What Is History? London: Pelican.

Clavin, PAtricia. (2013) Securing the World Economy: The Reinvention of the League of Nations, 1920-1946. Oxford: Oxford University Press.

COMMISSION ON Global GovernanCE. (1995) Our Global Neighbourhood. Oxford: Oxford University Press.

COTTRELL, PATRICK. (2014) Lost in Transition? The League of Nations and the United Nations. In Charter of the United Nations: Together with Scholarly Commentaries and Essential Historical Documents, edited by Ian Shapiro and Joseph Lampert. New Haven: Yale University Press.

Cull, Nicholas John. (1995) Selling War: The British Propaganda Campaign against American "Neutrality" in World War II. New York: Oxford University Press.

DREZNER, DANIEL W. (2013) “'Good Enough' Global Governance and International Finance," Foreign Policy Blogs. Available at http://foreignpolicy.com/2013/01/08/the-rise-of-goodenough-global-governance/ (Accessed January 30, 2013).

GadDIS, John LewIS. (1986) The Long Peace. Cambridge, MA: MIT Press.

GILPIN, RoBerT. (1981) War and Change in World Politics. Cambridge: Cambridge University Press.

Goldin, IAN. (2013) Divided Nations: Why Global Governance Is Failing, and What We Can Do about It. Oxford: Oxford University Press.

Goldstone, RichARD. (2014) Foreword: The United Nations War Crimes Commission Symposium. In The United Nations War Crimes Commission the Origins of International Criminal Justice, edited by William Schabas, Carsten Stahn, Dan Plesch, Shanti Sattler, and Joseph Powderly. Criminal Law Forum 25 (1 \& 2): 9-15. 
GOODRICH, LELAND M. (1947) From League of Nations to United Nations. International Organization 1 (1): 3-21.

Hale, Thomas, David Held, And Kevin Young. (2013) Gridlock: Why Global Cooperation Is Failing When We Need It Most. Cambridge: Polity Press.

Helleiner, ERic, Martha Finnemore, Michelle Jurkovich, KATHRYn SiKKinK, AND AmitaV Acharya. (2014) Principles from the Periphery: The Neglected Southern Sources of Global Norms, a special "Forum," Global Governance 20 (3): 359-481.

HurRell, ANDREw. (2002) Foreword to the Third Edition. In Hedley Bull, The Anarchical Society. New York: Columbia University Press.

IRIYE, AKIRA. (2014) Global Interdependence: The World after 1945. Cambridge: Harvard University Press.

Kimball, WARREn F. (1969) The Most Unsordid Act: Lend-lease, 1939-1941. Baltimore: Johns Hopkins University Press.

Lebedev, IgOR. (1997) Aviation Lend-Lease to Russia. Moscow: Nova Science Publishers.

LIBERAL JEWISH SYNAGOGUE LONDON. (1945) Service of Thanksgiving for the Final Victory of the United Nations in the World War of 1939-1945 and for the Ensuing Peace, August 19th, 1945. Available in the British Library, London.

MEARSHEIMER, JoHn J. (1994/1995) The False Promise of International Institutions. International Security 19 (3): 5-49

MURPHY, CRAIG N. (1994) International Organization and Industrial Change: Global Governance since 1850. Cambridge: Polity Press.

PATRICK, STEWART. (2014) The Unruled World: The Case for Good Enough Global Governance. Foreign Affairs 93: 58-73.

Pedersen, Susan. (2007) Back to the League of Nations. The American Historical Review 112 (4): 1091-1117.

Plesch, Dan. (2011) America, Hitler and the UN: How the Allies Won World War II and Forged Peace. London: IB Tauris.

Plesch, Daniel. (2004) The Beauty Queen's Guide to World Peace: Money, Power and Mayhem in the Twenty-first Century. London: Politicos.

Plesch, Dan, AND Shanti SATTLER. (2013) Changing the Paradigm of International Criminal Law: Considering the Work of the United Nations War Crimes Commission of 1943-1948. International Community Law Review 15 (2): 203-223.

Plesch, Dan, And Thomas G. Weiss, Eds. (2015a) Wartime Origins and the Future United Nations. London: Routledge. 
Plesch, DAN, And ThOMAs G. Weiss (2015b) 1945's Lesson: “Good Enough” Global Governance Ain't Good Enough. Global Governance 21 (2): 197-204.

RANSHOFEN-WERTHEIMER, EGON FERDINAND. (1945) The International Secretariat: A Great Experiment in International Administration. Washington, DC: Carnegie Endowment.

ReInISCH, JessiCA. (2013)"Auntie UNRRA" at the Crossroads. Past \& Present 218 (8): 7097.

REINISCH, JESSICA. (2011) Internationalism in Relief: the Birth (and Death) of UNRRA. Past \& Present 210 (6): 258-289.

REINISCH, JeSSICA. (2008) We Shall Rebuild Anew a Powerful Nation: UNRRA, Internationalism and National Reconstruction in Poland. Journal of Contemporary History 43 (3): 451-476.

RaghaVAn, SRINATH. (2014) The United Nations and the Emergence of Independent India. In Charter of the United Nations: Together with Scholarly Commentaries and Essential Historical Documents, edited by Ian Shapiro and Joseph Lampert. New Haven: Yale University Press.

Roosevelt, Franklin D. (1944) Message to the ILO Conference. 20 April 1944. International Labor Organization, 26th Session, Philadelphia, 1944, Verbatim Record of Proceedings 2. Available at http://www.ilo.org/public/libdoc/ilo/P/09616/09616(1944-26).pdf (Accessed March 20, 2015).

Roosevelt, Franklin D. (1943) The Nations Have Common Objectives, 9 November 1943. Available at http://www.ibiblio.org/pha/policy/1943/1943-11-09c.html (Accessed March 20, 2015).

Rosenau, James N., And ERnst-Otto Czempiel, EdS. (1992) Governance Without Government: Order and Change in World Politics. Cambridge: Cambridge University Press.

RugGie, JoHn GERARD, ED. (1993) Multilateralism Matters: The Theory and Praxis of an Institutional Form. New York: Columbia University Press.

SCHWARTZBERG, Joseph E. (2013) Transforming the United Nations System: Designs for a Workable World. Tokyo: United Nations University Press.

SHAPIRO, IAN, AND JOSEPH LAMPERT. (2014) Introduction. In Charter of the United Nations: Together with Scholarly Commentaries and Essential Historical Documents, edited by Ian Shapiro and Joseph Lampert. New Haven: Yale University Press.

Sinclair, Timothy J. (2012) Global Governance. Cambridge: Polity Press.

SKARD, TORILD. (2008) Getting Our History Right: How Were the Equal Rights of Men and Women Included in the Charter of the United Nations? Forum for Development Studies 1 (1): $37-60$. 
Slaughter, Anne-Marie. (2004) A New World Order. Princeton: Princeton University Press.

UNDP. (2013) Human Development Report 2013: The Rise of the South: Human Progress in a Diverse World. New York: UNDP.

UN WAR CRIMES COMMISSION. (1948) Information Concerning Human Rights Arising from Trials of War Criminals, E/CN.4/W/19. 15 May 1948. Available at http://www.unwcc.org/wpcontent/uploads/2013/04/UNWCCUN-HRs-Report.pdf (Accessed March 20, 2015).

VAn Tuyll, Hubert P. (1989) Feeding the Bear: American Aid to the Soviet Union, 19411945 Westport, CN: Greenwood Press,

Webster, ANDREW. (2005) The Transnational Dream: Politicians, Diplomats and Soldiers in the League of Nations' Pursuit of International Disarmament, 1920-1938. Contemporary European History 14 (4): 493-518.

WeISS, Thomas G. (2013a) Global Governance: Why What Whither. Cambridge: Polity Press.

Weiss, Thomas G. (2013b) Humanitarian Business. Cambridge: Polity Press.

WeIss, Thomas G. (2012) Renewing Washington's Multilateral Leadership. Global Governance: A Review of Multilateralism and International Organizations 18 (3): 253-266.

Weiss, Thomas G., AND Adriana ERThal ABDEnuR. (2014) Introduction: Emerging Powers and the UN-What Kind of Development Partnership? Third World Quarterly 35 (10): 17491758 .

Weiss, ThOMAs G., AND RAMESH ThAKUR. (2010) Global Governance and the UN: An Unfinished Journey. Bloomington: Indiana University Press.

WeISS, ThOMAS G., AND RORDEN WILKINSON. (2014a) Global Governance to the Rescue: Saving International Relations? Global Governance 20 (1): 19-36.

WeISS, ThOMAS G., AND RORDEN WILKInSON, EDS. (2014b) International Organization and Global Governance. London: Routledge.

WiLD, PAYSON SiBLEY. (1942) Machinery of Collaboration Between the United Nations. New York: Foreign Policy Association.

Williams, ANDREW J., AmElia HADFIEld, AND J. SimON RofE. (2012) International History and International Relations. London: Routledge.

WoOlner, DAVID B., WARREN F. KimbaLl, AND DAVID REYNOLDS, EDS. (2008) FDR's World: War, Peace, and Legacies. New York: Palgrave Macmillan. 